\title{
Lembaran
}

Sejarah

\section{Urban Citizenship:}

\section{A Case Study of Philanthropy by Missionaries in Magelang Municipality}

\section{YUDIANTO}

Universitas Gadjah Mada

\begin{abstract}
This study will answer the question of how far the case of philanthropy action by zending in the Magelang City can be understood as citizenship in the context of the early 20th century? By looking at the relationships between philanthropists and institutional of city council (gemeenteraad) it is expected to clarify their position and function in the early 20th century of colonial cities. In addition to indicating the strengthening of civil society, the case is part of the urban community's efforts to contribute various forms of participation that are not merely interested in politics or the movement of the nation.
\end{abstract}

\begin{abstract}
Abstrak
Studi ini akan menjawab pertanyaan sejauh mana kasus aksi filantropi oleh zending di Kota Magelang dapat dipahami sebagai citizenship dalam konteks awal abad ke-20? Dengan melihat hubungan-hubungan yang tejadi antara filantropis dengan institusi dewan kotapraja (gemeenteraad) diharapkan dapat memperjelas posisi maupun fungsi masing-masing dalam perkotaan kolonial awal abad ke-20. Di samping mengindikasikan penguatan masyarakat sipil, kasus tersebut merupakan bagian dari upaya warga kota untuk turut memperluas beragam bentuk partisipasi yang tidak semata-mata berminat pada politik maupun gerakan kebangsasan.
\end{abstract}

\section{Keywords:} city council; philanthropy; citizenship

Kata kunci: dewan kotapraja; filantropi; kewarganegaraan 


\section{Introduction}

This article explores the case of philanthrophy by the Protestant missionary in the early twentieth century in Magelang, an area located in the hinterland of Central Java. The missionary effort establish service institutions for poor people went hand in hand with the growth of Magelang city itself, a part colonial city growth in the early 20th century. This article focuses on the relationship between philanthrophy and municipal institutions of the Magelang municipal council (Gemeenteraad). This was a council establish on the Decentralization Law of 1903 and aimed to modernize the government of the Netherlands Indies. The case can be interpreted as a citizens participation in development in a colonial context, so that its comprehension becomes important because it marks the strengthenign of civil society.

The discourse on civil society can be defined from two points of view; conflict perspective and social capital (Guan, 2004: 2). The conflict perspective puts civil society as a countervailing force to the state, while social capital places civil society as a complementary force. Both points of view refer to the two great ideologies of the world, Marxism and Liberalism. Currently, the urban historiography of Indonesia is generally dominated by nationalist movements with a socialist framework or conflict perspective and as a result exclude non-indigenous civil society groups. The idea of civil society in this article, as will be demonstrated in the case of philanthropy by the missionary of society, i.e. by European society, was conservative in nature, or in other words does not seek to change the colonial relationship different from nationalist civil society groups. The assumption here is that the socio-political relations within the colonial framework are complex, for the European can not always be called colonialists, nor are nationalists who are not always opposed to the existence of the colonial government. This creates its own dilemma, such as where will the position of those who are not located on the two poles that are firmly-between nationalist and colonialist-in the historiography of Indonesia.

The main question of this paper is to what extent the description of citizenship can be understood through the institutional relationships between civil society and the municipality. This article will describe two aspects. First, the context of the development of the municipal colonial institution at early 20 th century which had received a decentralization policy. The description will focus on the municipal council (Gemeenteraad) of Magelang as a representation of the colonial civil society. Second, the philanthropy work of the missionary in creating a center for the indigenous poor in Magelang. It will describe the relationships between municipal council members with missionary figures, especially in the discussion forum of municipal council meetings. From these discussions, the observation of the missionary in this article are not only socio-religious, but it can be broader. If the most important principle of democracy is citizenship (O’Donnell, 1993), it can be stated that the case of 
philanthropy missonary in Magelang support democratization within the urban environment of the early 20th century Netherlands-Indies. This is because the performance of philanthropic missionary is inseparable from the citizen participation in the discussions in the forum of the municipal council. However, participation and democracy in early 20th century should be underlined on a limited, relative and dynamic character. The limited participation, especially the political participation of citizens, was caused by the logic of colonial racism and exacerbated by repressive policies under the guise of creating rust en orde since the 3rd decade of the 20th century (See Scholten, 1999: 54-73). While the relative and dynamic nature departs from the assumption that the discourse of democracy should be developed more broadly in Indonesian society, it is not about how proper and correct democracy has been applied, but how far the discourse of democracy has emerged (See Suseno, 1995). Although Joost Cote states that colonial democracy is an oxymoron or a contradictorion, he also states that the discourse of democracy in the Western and modern sense has been absorbed in the first decade of the 20th century (Cote, 2005).

\section{Civil Society in the Indonesian Urban's Historiography}

The study of the Indonesian urban history, especially the last colonial period (the late 19th century to the mid-20th century) may be interpreted into three outlines. First, the study that places urban areas as the context to explain the rise of nationalism from its rising middle class. This was carried out by W. F. Wertheim in his study of the transition of Indonesian society where newly priyayi as urban and educated citizens will have an important role in the development of national awareness as well as future social and political developments (Wertheim, 1999). Sartono Kartodirdjo describes the conditions of urban history in the early 20th century as a social space which triggered the rise of "national integration", a concept which also led to the revival of the national movement (Kartodirdjo, 1992). Adrian Vickers, meanwhile, with an emphasis on the "modern flavor" growing in urban space also states that the city plays an important role in creating a sense of Indonesia for the people whom the Dutch called "indigenous". He further argues that modern sense is important in forging the nationalism of Indonesians (Vickers, 2005). Similarly, the series of books titled "Indonesia dalam Arus Sejarah" which is the official government approved history of Indonesia, has a sub-chapter or section that highlights urban history followed by chapter "the rise of nationalism" (Abdullah, 2009). Meanwhile, the urban space creating more radical impulse of nationalism is described by W. H. Frederick. The city is portrayed as a contest arena between indigenous people driven by new priyayi groups and municipal governments as a representation of the colonial government. Their opposition came to a radical extent that led to an Indonesian revolutionary movement 
(Frederick, 1978). The history of city in this pattern is also encountered in historiography which takes the focus on the period of the revolution (post1945). Despite the different explanations, the historiography of the revolution in various cities follows the flow of understanding that the city is a space that stimulates nationalist movements or for national goals that must be in conflict with the Dutch colonial power itself. ${ }^{1}$ They are the studies of local cities history such as Surabaya, Bandung, Jakarta, etc. (Smail, 2011; Cribb, 1990). The emphasis on aspects of socio-political conflict in urban studies (especially between indigenous and colonial powers) is then followed by later historiographies (eg, Basundoro, 2013).

Second, are urban study that looks at the the colonial city within the context of modernization. It is necessary to present the research program of Indonesia Across Orders: Reorganization of the Indonesian Society 1930-1960 organized by NIOD (Nederlands Instituut voor Ooorlogsdocumentatie). The research program in collaboration with these institutions (LIPI, PSSAT and UGM and Airlangga History Department) produced various interesting publications and provided new understanding of urban history. Decolonization as a process of continuity and the change in space and time. The various study in this program are crucial in creating opportunities to understand the city not only as an arena of domination but also one of modernity. ${ }^{2}$ A recent example of this study is a book edited by Freek Colombijn and Joost Cote, which contains a collection of writings of urban experts both from historians and other social sciences with various themes such as settlements, health, transportation, waters and other social issues in a city from the second decade until the middle of the 20th century (Colombijn \& Cote, 2014). This is an interesting point for the development of Indonesia urban historiography where the narratives have been proved that the city was not merely a space for nationalists. Modernity creates an unavoidable situation that demands new behavior to everyone and realizing a reality that a city is the result of

1) Today there has been an attempt to explore the reality of Indonesian-Dutch war conflicts that are free from the rigorous narratives of the limits of "warriors" and "enemies" with the publication of revolutionary historiography or "war" historiography utilizing new sources, that is ego-document considered to represent the voices of battle actors in the field. look at Gert Oostindie, Dutch Soldier in Indonesia 1945-1950 (original title: Soldaat in Indonesie 1945-1950: Getuigenissen van een oorlog aan de verkeerde kant van de geschiedenis). (Jakarta: KITLV-Yayasan Obor, 2016).

2) Many studies have been produced and published in relation to the NIOD research program, such as Freek Colombijn, et al, Kota Lama Kota Baru Sejarah kota-kota di Indonesia. Yogyakarta: NIOD, Ombak dan Jurusan Sejarah Airlangga University, 2005; Abdullah and Sukri Abdurrachman (ed), Indonesia Across Orders: Arus Bawah Sejarah Bangsa (1930-1960). (Jakarta: LIPI Press and NIOD, 2010); as well as various books on urban symbolism such as Dedi Irwanto Santun, Venesia dari Timur : Memaknai Produksi dan Reproduksi Simbolik Kota Palembang dari Kolonial sampai Pascakolonial. (Yogyakarta: Ombak, 2011); Ilham Daeng Makkelo, Kota Seribu Gereja Dinamika Keagamaan dan Penggunaan Ruang di Kota Manado. (Yogyakarta: Ombak, 2010); and others. 
a continuous process of urbanization, modernization and decolonization. This means that there is one thing, namely modernity that does not escape from the process and can not be denied by the people of Indonesia. Thus, the decolonization cannot be denied that people culturally accepted the ideas brought by the West which is adopted in line with the wave of modernization.

Third, are studies which looks at the middle class but does not tie them to the dicussion on political nationalism, but on cultural citizenship. Henk Schulte Nordholt offered this idea of Indonesian urban history. He suggest reinterpretation for the view of conventional historiography that has placed the urban as a space that fosters the middle classes as a driver of nationalism to revolution. Not all urban middle classes agree and participate in the national movements openly and radically. Nationalism is too risky and potentially threatening their standard of living (Schulte Nordholt, 2011). Then they participate in a frame of cultural citizenship which is visible from their daily lifestyle, not the independence or revolution as the goal.

Without intending to negate its importance, the second and third outlines of the urban historiography according to the above categories can be expressed as a revision or new understanding of the urban historiography first outline. The first outline according to the above categories is the result of historical understanding centered on the narrative of national history. As it is known that the early national history was declared in 1957, precisely at the First History Seminar in Yogyakarta, was a history that emphasizes the importance of the national inspiration, the elements of independence and the struggle of the Indonesian nation. Muh. Yamin states that the philosophy of Indonesian history is the Indonesian nation with the spirit of Indonesian nationalism, namely the sense of patriotism towards the unity of the nation, the homeland and the cultural roundness in the establishment of the nation bulding Indonesia (History Seminar I, 1958). The spirit of times has influenced the style of the national historiography, including the urban historiography itself.

Along with its development, national historiography can not be separated from various criticisms. The writing of Indonesian history inspired by the spirit of nationalism has been understood solely as a reaction to colonialism or Dutch colonial government. The approach of Indonesia-centric in the writing of history is defined simply as placing the Dutch as enemies and indigenous people as the main actors. According to Bambang Purwanto, Indonesia-centric historiography's basic premise is actually not that different from colonial historiography (Bambang Purwanto, 2006). Realities that are actually part of Indonesian history has marginalized because the actors of that reality are considered "not indigenous". The groups belonging to or related to colonial powers or socio-economically benefited by the relations of colonial power, such as the Indo, Tionghoa or bureaucrats and aristocrats, have no place in 
Indonesian history (Pradipto, 2011: 103). Similarly, with the local history writing, which originally aims to uncover more diverse realities in certain locality, many are forced to stick to the mainstream of national history. So, that what appears are national history in local version, local history study only contribute to national history (see Abdullah, 2010: 1-46). Thus, it is necessary to consider looking for other alternatives in the writing of Indonesian history by extending the interpretation relating to the various realities of the past itself. Some of the studies that have been done are showing the diversity of interpretations of the identification of nationalism itself in a case study, such as Javanese nationalism, Javanese aristocracy and Indies nationalism (Shiraisi, 1986; Fakih, 2012; Pradipto, 2011).

In this regard, the study of urban history should be released from existing national historical framework. If Schulte Nordholt offers an idea in the form of lifestyle modernity as the focus, then Bambang Purwanto suggests that the study of urban history raise the masyarakat kebanyakan in the daily life history construction framework (See Purwanto in Schulte Nordholt, 2013: 245).

The existence of the alternative offer does not mean negating the importance of the urban history study that has been there before. Despite the differences in the interpretive view of urban reality, the three urban historiography outlines mentioned above are generally considered to be drawn an element of continuity. All three, in addition to the implications of urbanization, are also a manifestation of participation (surely not just political participation) of the urban community. The final outcome of the three historiographic outlines, namely nationalism-independence, modernity and cultural-citizenship are part of the expansion of public participation in urban contexts that occur in various aspects (politics, social, culture, etc.). So the urban dynamics can be assumed to be moving because of the diverse participation that occurs at various levels in various racial, ethnic and class groups. The urban study that have been conducted as mentioned above thus provide an important description as the understanding of the urban history development in Indonesia.

If the important aspect of the development of urban space is "participation" then it is necessary to review how far the urban society participates in the urban realm. This means that the discussion context to do is on the rise of urban civil society that is able to determine the urban dynamics itself in various directions. Nevertheless, the civil society is formed by various situations and conditions that are happening in the city so that the city also gives influence to the dynamics of the community. Therefore, both the city as space and society as an active element are intertwined and influenced. 


\section{Municipal Council as Space of Citizen}

Robert Putnam, in his study of democracy in Italy assumes that citizenship tradition at the local level can grow due to decentralization. Decentralization will stimulate the citizens participation in a wide range of relationships to create a civil society. It is the bonds within the civil society that in time will encourage the life of democracy, or in other words a civic awareness realized through participation in the civil society that will foster the values of social capital that encourage the creation of democracy (Putnam 1993). Of course Putnam's thesis related to democracy can not be fully applied in the colonial order, yet at least we can explore how far the principles of citizenship have begun to emerge, especially with the implementation of decentralization at the beginning of the 20th century in the Netherlands-Indies.

The municipal council was formed as a consequence of the decentralization policy. Discussion of this decentralization effort has been going on since the 19th century among the Dutch parliament, both Liberal and Socialist groups, both private and non-private shareholders, stressed the need to escape the control of the Netherlands. The main objective of decentralization was to promote commerce by freeing the Indies government from the control of the Netherlands which in its development then elements of autonomy increasingly come to the fore (Furnivall, 2009: 280). The ratification of the Decentralization Laws 1903 was followed by the formation of local councils in 1905 for the three main cities of Java, while the other cities followed one to several years later. The colonial city was chosen as the first attempt to implement decentralization as in the city the Europeans were exist, European-educated and considered to have adequate technical and managerial skills (Fakih in Cote, 2015: 152).

The municipal council (Gemeenteraad) is a council that functions to deliberate and determine the policies and budget of the municipal government. Besides the Europeans, this council was also composed of indigenous and a small number of Chinese and Arab members. The council representing the various groups of people living in the city was something entirely new in the Indies, the result of the adoption of the city council form in the Netherlands. The members of the city council could be declared as citizens of the city who participate in the scope of the city's both political-government and society. Nevertheless, participating in the council was limited because of the regulations that require members of the council must come from the rich and be fluent in Dutch, limiting non-Europeans.

Freek Colombijn in his study of Padang city describes the municipal council as a political game arena (Colombijn, 1995). Council members seek each other to achieve their political goals with diverse maneuvers both within the council itself and in relation to central government authorities in Batavia in terms of autonomy demands. Colombijn suggests that autonomy is not 
simply given by the central government, but must go through the continuous struggles of the council members (Colombijn 1995: 264).

Despite these weaknesses, the presence of the municipal council was a good historical start for the city's development. This was a council that has the function of a city government policy designer, so that the city authority was no longer absolutely in the hands of the Government's Binnenlandsbestuur (Department of Internal Affairs). Although initially municipal councils only carried out administrative tasks from higher levels to the local level, autonomy became increasingly evident in its development. The post of chairman of the municipal council was no longer an assistant resident after 1916, but an elected mayor, meaning thta the council was no longer subject to the local Resident. One year later members of the municipal council were elected and after 1926 the Colleges van Wethouders were introduced (Nas, 1990). The development indicates that the inhabitants who sat in the municipal council increasingly had a strong position and more freely in playing a role for the interests of the city. Perhaps this is the form of the strengthening of "citizen" of the state because some of those who sat in the municipal's executing council were not appointed by the government but through electoral mechanisms, although these elections were limited to certain social classes.

It was not easy to become a member of the municipal council. In addition to general conditions such as age over 25 , living in the municipality concerned and the residents of the Netherlands-Indies, municipal council members must also be literate men with good Dutch language skills and must be a taxpayer of not less than $\mathrm{f} 300$ per year (Locale Belangen, Nov. 1, 1932: 869). The latter requirement required a member of the council to be from the rich, where in Java and Madura about $80 \%$ of the population was not of the taxpayer group (Vickers,: 27). In addition, besides the electoral mechanism, some members of the council were also the results of the appointment by the government. Some of the things caused Europeans always got a larger seat in the council.

Members of the council were usually dominated by businessmen or traders, military officers, local community leaders as well as professional groups such as lawyers, engineers, doctors and teachers. In Magelang, council members composed of various professions, such as military personnel, businessmen, teachers, notaries, doctors and even regent. Names like Jongh Swemer, H.D.J. Apituley and L.H. Berg were some members of the council from the military element. Apituley was a member of the KNIL who had reached the rank of officer (lieutenant-colonel) among many other indigenous military personnel even as a health officer (Matanasi, 2012: 44). Apituley's career continued into the Volksraad (People's Council). He was a member of Sarekat Ambon and in 1929 co-founded Moluksch Politiek Verbond. Berg was a lieutenant-colonel in his military service, an Indo-Europeesch Verbond (Indo-European League) and a leader of the Boedi-Rahajoe health foundation. 
Names like R.T. Danoekoesoemo, R. Soeriomihardjo, R.M. Soejadi, R.M. Soeprapto and M.K.H. Soebroto were Javaneses priyayi either noble or new or professional priyayi. Danoekoesoemo was the Regent of Magelang in the early twentieth century, once a member of the Mardiwara association, an association of elits priyayi pre-Budi Utomo concerned about the progress of science, while Soebroto was a Malay language teacher at OSVIA Magelang, a school that produced cadres of indigenous government officials (pamong praja). In addition, Soebroto was one of the board of PGHB, an association of teachers of the Netherlands-Indies as well as one of the pioneers of the Boemi-Poetera insurance company. He had been offered to sit as a permanent director of Boemi-Poetera but refused and chose to pursue his profession as an educator. Some of the municipal council members who came from businessmen/entrepreneurs were J.A. Loze, J.M.J. Van Eijk, S.D. Jansz, etc. Loze was a star-rated hotel businessman in Magelang, while van Eijk and Jansz were the owners of shopping centers in the city. Doctors who were board members include C.J. Lumkeman, R. Tumbelaka, Van der Meer, etc. Lumkeman was a major doctor who served in the military service and after leaving the Magelang Municipality Council then established a health service in Kediri (Regeerings-almanak N.I 1923: 85). Tumbelaka was a native doctor who was quite successful in his career. Born in 1880 in Manado, he together with Ratulangi founded the Minahasa Union in 1927, where in the history of the Indonesian idea he participated in calling for solidarity among ethnic groups in Indonesia (Elson, 2009: 44). Tumbelaka was the leader of the Magelang Psychiatric Hospital until 1928, which was later appointed by the government as the Inspector of Psychiatric Hospital Affairs for the Netherlands-Indies (Indische Courant: 06-12-1928). Some examples of the composition of the council members show that members were filled by people not only of different races but also of various ethnicities and professions. They were unlikely to leave their profession even though they have become council members (although some were actually government employees because of the appointment) and sometimes the member's position was used to support his profession.

The municipal council had also became the bridge for its members to strengthen its interests as well as to learn politics, especially for Indonesian people. Indigenous council members could take advantage of the municipal council's institutions as a stepping stone in the struggle for aspiration from the local level. In Jakarta for example, M.H. Thamrin as a representative of the indigenous population could freely protest against the discriminatory policies of city governments in the budget (Blackburn, 2014: 168). As well as the example in Padang, the municipal council became a good tool to strengthen the legitimacy for members more freely. One member of the Padang Municipal Council, Abdul Hakim succeeded in becoming a member of the council 
consecutively until he became a mayor in 1947. It could be done because as a member of the council he established a good cooperative relationship with the Europeans in spite of his allegiance to the indigenous population so he became famous between them. Meanwhile, Roestam Effendi got "training" from his membership in Padang Municipal Council until he succeeded in becoming a member of parliament in the Netherlands (Colombijn, 2006: 138). While dr. Soetomo in Surabaya also used the municipal council as a means for his struggle. Soetomo voiced the importance of the autonomy extension which is not only to the municipality, but also to the village levels (Inlandsch Gemeente) (Dhont, in Jamil Gunawan, et al., 2005). Therefore, the municipal council is a means for "citizens" to express their participation primarily for political interests in addition to the other interests, as well as the entity of colonial democracy at the local level.

\section{The Practice of Missionary Philanthropy and the Overview of Colonial Democracy}

Putnam's definition of decentralization has the implication not only for the growing tradition of citizenship, but also has the potential to stimulate civil society organizations and networks (Putnam, 1993). The opening of local community participation through various associations can be interpreted by the opening of civil society networks. The characteristic of a healthy civil society is the existence of associations. In the context of the early twentieth century, Magelang was one of the few colonial cities where there was a symptom of this civil society strengthening. Voluntary associations by missionaries was a strong example for this.

Magelang belonged to Kedu Residency, a residency established in the second decade of the nineteenth century by the colonial government. It was located in the middle of a transportation line that in the mid-19th century has connected the inland city of Yogyakarta with the coastal city of Semarang. Magelang can not be separated from the phenomenon of poverty that occurred during the 19th century. But it is not the place in this article to investigate the causes of poverty in this region. It can be seen in various literatures that examine the subject of the colonial economy of the nineteenth century. The cultivation system (cultuurstelsel) with its various consequences as well as population density factor, slow rice production, inequality of distribution of land ownership and disease are generally regarded as triggers (Purwanto, 1990; Suhartono, 1993). The existence of such poverty then encouraged an investigation into what was called mindere welvart by the Dutch Queen in 1901 along with the development of ideas about efforts to prosper the indigenous population in the Indies (ethical politics). Along with the development of prosperity, missionaries have a role that was not less important, especially in terms of health and education services (Furnivall, 2009: 401). It should be 
understood that the mission was not only limited to the spread of religion, but also helped the penetration of Western civilization (Kartodirdjo, 1992: 44). Of the few churches in Magelang, the Gereformeerd mission was one of the important. The existence of the church played a role in the effort to reduce poverty in this region.

\section{Merkelijn's Blondo Poor Colony}

The Gereformeerd mission started its activities in Central Java in 1899 after the decision of the Dutch Gereformeerd Churches Synod at Middelburg in 1896 came into force. This mission was under the auspices of Zending van de Gereformeerde Kerken in Nederland (ZGKN) which replaced the previous mission institution, Nederlandsche Gereformeerde Zendingsvereeniging (NGZV). The task of mission in Magelang included in the Kedu region was held by the Middelburg Church sender in cooperation with the Zeeland Church, Noord Brabant and Limburg (Soekotjo, 2009: 279). Each church had its own messenger, so the mission control center was in the hands of the church sender in the Netherlands and the spearhead was the missionaris. The missionaris assigned by the Middelburg Church to preach at Kedu was A. Merkelijn.

Merkelijn and his wife arrived in Java, precisely Jakarta (Batavia) on January 26, 1912. Then they headed to Central Java in the same year until they later lived in Magelang. It was not a difficult thing for Merkelijn to quickly recognize the condition of the surrounding society. He was not alone, his fellow missionaries had been spread in various surrounding areas, both in Kedu and Yogyakarta. The first attempts were to establish primary schools such as Hollandsch Chineesche School (HCS), Hollandsch Javaansche School (HJS) and in 1921 even opened Europeese Lagere School (ELS) in Magelang city. Dutch elementary school for Javanese (HJS) was founded in three places, namely Jambon, Kejuron and Poncol (now Ahmad Yani street). Dutch elementary school for Chinese people (HCS) is opened in Kemirikerep (Tidar street, now SMIP Wiyasa) (Atmodjo: 15-16). In addition, Merkelijn also attempted to establish the Huishoudschool (School of Household) in 1928.

In order to carry out his mission, Merkelijn had built a group of indigenous people. The names such as M. Hakim, M. Sadi Martawihardja and R. Prawira Soeganda were listed as important people around Merkelijn. They were Javanese Christian teachers who helped Merkelijn as well as the religion teacher. In addition to these teachers, Merkelijn was also assisted by a Javanese who would replace his duties as a priest, namely Idris Nakam Siswowasono. He was also a teacher who originally lived in Kebumen and in 1924 was appointed as a religion teacher assisting Merkelijn in Magelang. Four years later Idris Nakam was appointed as a Java Congregation Priest. Idris Nakam was the first priest appointed by the indigenous people in the Merkelijn zending work environment. The support of these indigenous teachers convinced Merkelijn in his efforts to open schools. 
Figure 1.

Ds. Merkelijn with Ds. Idris Nakam Siswowasono and her family

Source: The private collections of Soegeng family (son of Ds. Idris Nakam Siswowasono)

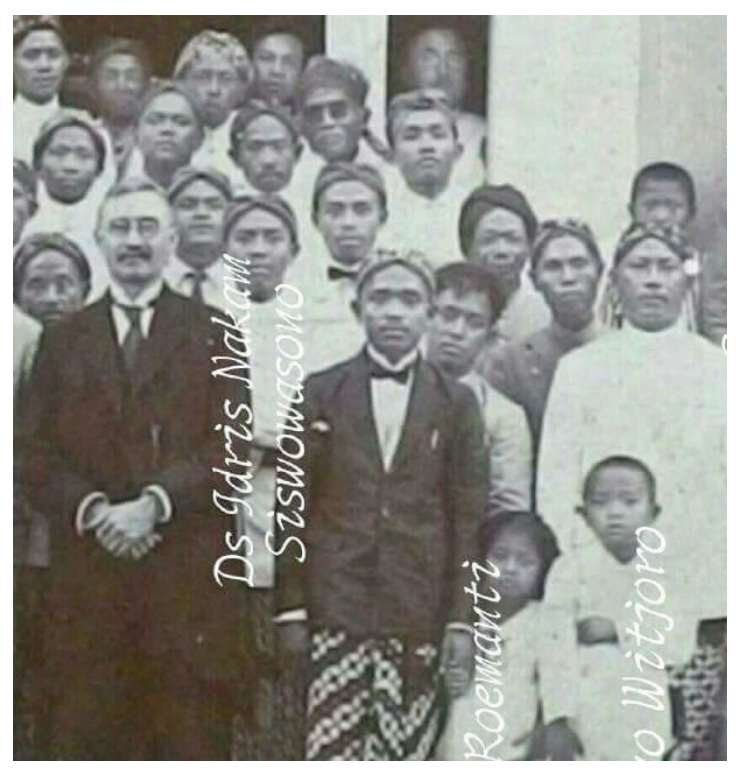

Besides opening schools, Merkelijn's important effort was the establishment of rehabilitation center for the poor. Effort to overcome poverty at that time was known as armenzorg (poor care). In his autobiography, Merkelijn describes the conditions in Magelang which are of concern because of the poverty (Merkelijn 1940: 194):

"Magelang required a poor colony where poor Javanese could be involved. It was happening every Sunday that the invasion of poor Javanese, in groups approached the Europeans houses for alms. They should be in the hospital, there were blind people guided by children with sticks, Javanese unkempt, paralyzed/ disabled, etc.” ${ }^{3}$

The Merkelijn's statement above reflected the poverty in Magelang. The large number of beggars and unkempt people encouraged Merkelijn to offer the Magelang Municipality government a plan to establish a shelter for the poor Javanese. Similarly, people with physical disabilities such as blind and paralyzed whose live are dependent on others (Indische Courant, 18-03-1930). Eventually, Merkelijn managed to establish a shelter for them in Blondo, one of the villages on the side of Magelang road to Yogyakarta.

The shelter was known as the Poor House/Poor Colony. In the colonial government's report, there were many such poor shelters, especially in Java,

3) "Er was in Magelang behoefte aan een armenkolonie, waar arme Javanen, die langs de wegen liepen te bedelen, konden worden opgenomen. Er vond vooral des Zondags telkens een invasie van arme Javanen plaats, die zich met groepjes soms op de erven der Europeanen neerzetten en om een aalmoes vroegen. Velen van die armen hoorden in een ziekenhuis thuis. Daar zaten ze: de blinden, die aan een stokje door een kind werden rondgeleid, de Javanen met onverzorgde, vieze beenzweren, kreupelen enz." 
with different managers. Management was usually done by religious-based groups such as Church and Islamic mission (Muhammadiyah). However, there were also managed by groups that were secular or non-religious. Pieter Brooshooft, a newspaper journalist with De Locomotief who was also an important ethical figure, had been seeking a poor shelter in Semarang in relation to the famine at the end of 1901 . He planned to accommodate by providing care and useful jobs for the poor. Brooshooft's effort failed because it received no financial support from the government even though it had earned initial capital for the development obtained from various donations in the Indies as well as in Netherlands of $\mathrm{f} 30,000$ collected by Van Deventer (Scholten 1996: 48).

Merkelijn founded a poor shelter in the Blondo area and was recognized by the government in 1920 based on a decree dated July 1, 1920 No. 55. In this decree, it was mentioned that the government would help by providing subsidies of $f 400$ every year (Koloniaal Verslag, 1921: 168). The existence of this subsidy has shown that the existence of poor shelter was very much needed, especially in urban areas which were often found homeless and beggars (Djawa Tengah, 18-02-1918; Djawa Tengah, 18-04-1918).

Blondo Poor Colony was a vast shelter and the people inside, both men and women, were busy with various activities. Merkelijn tried to get them equipped with skills and trained with productive activities, such as making knitted handicrafts to be mats, doormats, woven fabrics and other household utensils. Patients with physical disabilities who were unable to walk for example, could also do this because it could be done while sitting. Interestingly, even the blind were still equipped with skills to make woven crafts..

The source of funding for the shelter was obtained from various parties or donors, such as private companies, Gereformeerde churches in the Netherlands and Indies, subsidies from both central and municipal governments and the sale of various crafts made by the residents of the shelter. The proceeds of this handicraft sale (mats, mats, woven fabrics, etc.) were later questioned when Merkelijn applied for subsidies to the Municipality (Merkelijn, 1941: 197).

The effort was a manifest step from Merkelijn to participate in advancing Magelang society and surrounding with forms of poverty alleviation and the provision of education in the shelter. The shelter with these characteristics was quite effective at that time to overcome the unemployment problem and reduce the turbulence that could emerge in the cities so that it could trigger poverty in all its forms, including beggars. This kind of social management model was subsequently adopted by the colonial government due to the explosion of unemployment during economic depression by building work centers (werkcentrale). This also included the imitation by religious institutions 
Figure 2.

Merkelijn with the

Blondo Poor House management

Source: 26 jaren op net

Zendingsveld.

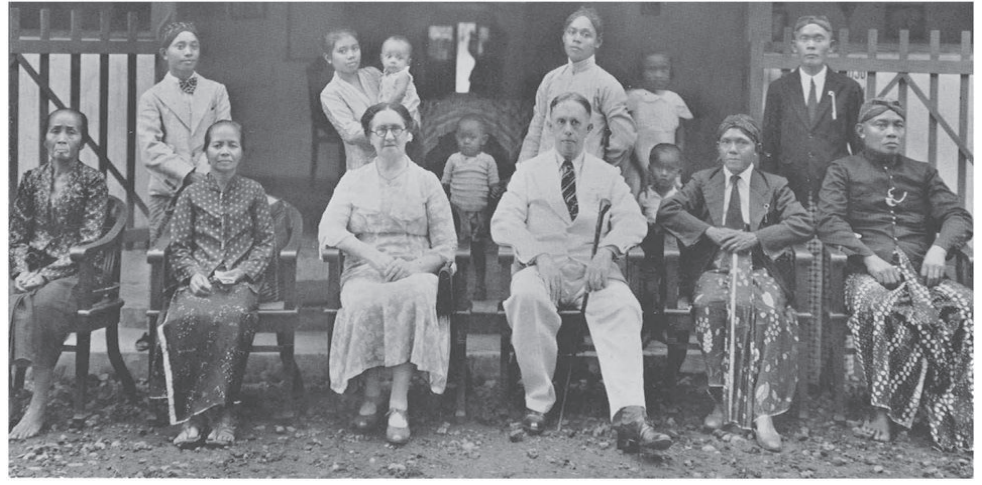

of Muhammadiyah in its social-humanitarian mission. Hilman Latief in his study states that the Muhammadiyah movement was inspired by Christian missions in its more advanced social endeavors (Hilman Latief, 2010: 17).

\section{Civil Society in the Municipal Council Discussion}

The social efforts promoted by Merkelijn could not be separated from municipal supports. Supports from municipalities in the form of financial aid or subsidies were given every month or year. But it was not easy for Merkelijn to appeal to the municipal council to help him, Merkelijn found himself in opposition to council members who refused to his efforts. Besides showing how the social services for the poor in the colonial period, discussions within the municipal councils reflecting the essence of democracy in the dialogue among the citizens themselves. The relationships between Merkelijn and municipal councils recorded in the minutes of council assembly in the early decades of the twentieth century reflected the course of colonial democracy at the local level and showed considerable distance or borders between civil society and the state. From there it can be seen that Merkelijn and his group are a reflection of the civil society who has a stake in providing and serving the needs of the society in which the state was incapable (unwilling) to provide it.

In 1923 Merkelijn appealed to the Municipal government to support his efforts in collecting beggars to Blondo. In his letter, Merkelijn asked the council to support f.1000 for the construction of the Blondo Poor House. At the beginning of his discussion, he got the supports of several council members, including K.H. Soebroto and R.L. Sastroamidjojo who agreed with Merkelijn's plan, with the provision of the municipal financial condition is sufficient (Notulen van den Gemeenteraad van Magelang, 9 April 1923). The two Javanese were council members who came from civilians and businessmen. Soebroto, as well as a teacher was also the founder of the Boemi-Poetera company, while Sastroamidjojo was listed as a member commision of the School of Engineering special for the indigenous in Magelang (Ambatchsscholen voor Inlanders). It is not clear what the reason for this was. 
Despite the support, this request had not been finalized. C.J. Lumkeman, a council member who worked as a military service physician, strongly rejected Merkelijn's request. Lumkeman believed that the native people who became beggars and vagrants were not out of necessity. Lumkeman seemed to think that the beggars did so on purpose. Meanwhile, the other council members prefered to take the middle course, that was agreeing to provide assistance but with a smaller nominal, f100 each year (Notulen van den Gemeenteraad van Magelang, 9 April 1923).

The different opinion in this session encouraged the chairman of the council to decide to implement the voting. A total of 12 council members presented were asked to choose three options for Merkelijn, providing direct assistance of f1000 as requested by Merkelijn, giving f100 each year or rejecting the request at all. The result of the vote finally decided to only provide subsidies of f100 to Merkelijn every year. This shows that not all council members supported Merkelijn's move.

The council decision, which only passed 10 percent of the requested grant, made Merkelijn reappealed a year later (1924) to increase the amount of the aid. This request was different from the previous one where Merkelijn did not mention the nominal demanded, but only mentioned that the amount was increased. This time Merkelijn got support from S.D.Jansz, a council member who always enthusiastically distributed Merkelijn's aspirations in the council forum. Jansz was a businessman. He was a council member from 1917 to 1928, the longest term of service amongst councilors. He was also a member of the Kedu Residency Council (Regeerings-almanak N.I., 1916-1928). Unfortunately, no further information about this person is found. One clue that can be known is that Jansz and Merkelijn were two associations leaders concerned with the education of poor children especially military descendants in Magelang regardless of the background of racial groups (Regeeringsalmanak NI, 1923: 198). This indicates that Jansz was an active man, or at least concerned with social affairs. Thus, Jansz and Merkelijn were two civil society figures who participated in social affairs of humanity, although both had different professions. Jansz's position on the council benefited Merkelijn because his aspirations could be represented.

With regard to subsidy for Merkelijn, Jansz recommended that subsidies be increased to f.50 each month (f.600/year) after previously arguing that municipal budgets were adequate. Jansz also argued that the existence of the Poor House was of course a big part in eradicating poverty and homeless in Magelang (Notulen Gemeenteraad van Magelang, 8-07-1924).

Jansz opinion was considered excessive by other council members. Some of them thought the fund was too high and suggested that its nominal value be reduced to f.500/year. Even one of the members, M.S. Bamberg stated that funding or subsidies should be the responsibility of the community 
rather than the government. Please note that Bamberg was a council member of a governmental group. He was an employee of the Cadastral Service in Magelang, precisely as a landmeter who supervised all officers of the entire land measurement section of Kedu (Regeerings-almanak N.I., 1924: 340). He stated that:

"...Armenzorg should be submitted to private initiatives and the first clearly show that the government is in a state of lack of money". ${ }^{4}$

Bamberg's statement shows that he did not see the social context that occurred at the time. Such associations in some places were also running due to support from government agencies, both central and local government. An example is an association to accommodate blind people in Bandung who received funding support from various municipal governments, such as Jakarta (Batavia), Bandung and Semarang. The Batavia government even assisted by giving 10 cents per person per day (Koloniaal Verslag, 1915: 2). In other places such as Malang, for example, the shelter for poor people managed by religious organizations such as Muhammadiyah also got support from Malang Municipality (Gemeenteblad van Malang, No.66,1934).

After the session was postponed for several weeks, Merkelijn's application was finally approved only f. 300 per year. This was even lower than that proposed by council members at the previous meetings where the lowest option was f. 500. Therefore, the subsidy granted by Magelang Municipality was only an increase of $\mathrm{f}$. 200 from the subsidy given in the previous year (Notulen Gemeenteraad van Magelang, 29-07-1924).

From the two subsidy allocation processes above observed in the minutes of the council meeting, there are several explanations that can be expressed. First, the course of the trial shows that it was not easy for Merkelijn to win the council's sympathy to support it. Although there were a handful of people who support it in council forums, the voice was always defeated by the rejecting voice. It is true that finally the subsidy was still given, but the process or the course of the agreement indicates the existence of contradictions between Merkelijn and the majority of the council members.

Capital needs for physical infrastructure might be a factor in the municipal allocation. During the Merkelijn appeal, Magelang Municipality had allocated the largest part of its budget to physical infrastructure. Approximately 47 percent of the total budget or $\mathrm{f} 156.846$ was included in the public works budget (Begrooting van de Gemeente Magelang, 1924). It is not surprising

4) “...armenzorg aan het particuliere initiatief behoort te worden overgelaten en eerst als duidelijk is aangetoond dat er geld tekort is behoort de Overheid bij te springen". Lihat "Agenda 3. Behandeling van het verzoekschrift van A.Merkelijn om verhooging van de subsidie ten behoeve van de kolonie te Blondo", dalam Notulen van de Openbare Vergaderingen van den Gemeenteraad van Magelang 29-07-1924, page. 255. 
that some council members disagree with Merkelijn's appeal.

Second, the council sessions was decided by way of voting. Voting has closed the opportunity for those who did not get support from other members to defend their opinions. The most votes made the decisive decision. Of course this created the impression that Merkelijn's effort was not supported by the municipal council.

The other factor could be seen in the third application for Merkelijn's appeal in 1927. The submission received a different response from the previous submissions. The council decided to conduct a survey to the Blondo Poor House first. Surveys were certainly an advance because the council members could see the conditions of the shelter directly. The survey also aimed to determine how much the amount of subsidy or "proper" funding to provide (Notulen Gemeenteraad van Magelang, 8 Maart 1927).

The visits were made to Blondo by several council members, namely H.D.J. Apituley, J. Darga and S.D. Jansz. As a result, reviewers gave different opinions on the Poor House. Apituley concluded that the use of the budget in the Blondo Poor House was too wasteful. Various reasons were then submitted to recommend that this subsidy increase for the Poor House be reviewed. He argued that the cost of consumption for the residents of the Poor House was considered too high. In addition, Apituley questioned the income of Blondo Poor House from the sale of carpet handicraft of f. 1400. Poor homes were considered to have been able to finance its own operations with the income.

Other members of the review council had different opinions. Jansz, who since 1924 appeared as a supporter of Merkelijn denied Apituley's opinion that Blondo Poor House did not need a grant just because it had income from selling carpet crafts made by the inhabitants. According to Jansz, the grants to this poor house would be used for the development of new buildings within the compound of poor houses so that donations from various parties were needed. Darga, a member of the review also proposed a middle course by approving an increasing assistance under conditionalities. The requirement was for Merkelijn to prioritize absorbing beggars and vagrants in Magelang rather than in other areas (Notulen Gemeenteraad van Magelang, May 5, 1927). This requirement showed the desire for municipalities to get reciprocity from the existence of Blondo Poor House.

Eventually, the council decided to raise the subsidy amount for the poor house after the vote. This third funding proposal by Merkelijn would be increased only by f. 25 per month. This occured after the conditional subsidy proposed by Darga was approved by another board member. Thus, the subsidy fund for this poor house became $\mathrm{f} 600$ per year. This small increase in subsidies caused some dissatisfaction because there were council members who disagreed. L.H. Berg, for example, was reluctant to approve the grant to the Poor House. Berg argued that funding for the Blondo Poor House 
could also be obtained from other local governments, not just Magelang Municipality alone. Berg was a council member who was a retired army officer. Lieutenant since 1892, served in military operations in Aceh, in a civilian position concurrently a member of the Central Java Provincial Council and head of the organization of the IEV (Liga Indo-Europe) of Magelang (Java Bode, 28-07-1892; Het Nieuws 15-09 -1911; Batavia Nieuwsblad, 23-09-1916.)

The case of appealing for subsidies by Merkelijn also occurred in the case of establishing schools. As stated earlier that Merkelijn's social participation in this city was also done in the realm of education with the schools opening. One of the schools to be founded by Merkelijn is the Huishoudschool, a vocational school dedicated to indigenous women in the city. The plan of the Huishoudschool's establishment by Merkelijn in 1927 did not seem to get a good response from the council members when Merkelijn applied for a subsidy for its establishment. Minutes of municipal council meetings recorded the rejection. The refusal to subsidize was based on the assumption of limited municipal budget if it had to provide a subsidy of 30 percent of its total development and operational costs, while 70 percent was ready to be certified by the central government through the Department of Education (Departement van Onderwijs). Chairman of the Municipal Council (P.M.Letterie) expressed his objection:

"The Municipal Council strive this year (1927) for a fund of $f$ 8000 allocated to the budget that is essential for the repair and renovation of roads, gullies and waterways, while there is still a long list of work to be done that can not be completed in a few years...."

The expression of the city council chairman above as if asserted that the affairs of physical infrastructure such as roads and sewers were more urgent than the provision of social-educational infrastructure. This refusal was also expressed by members of the Berg council who previously also questioned the granting of subsidies to Merkelijn in relation to Blondo Poor House. Berg stated that the establishment of a school driven by Merkelijn was not so urgent that it needed to be reviewed. Moreover, Berg also questioned the background of the school which was feared would be managed based on Christianity because it was founded by Merkelijn. Berg made this as an excuse to refuse to support the establishment of this school. Berg's allegations were later strongly denied by Jansz, who had originally defended Merkelijn. Jansz assured the

5) “de Gemeenteraad met zeer veel moeite dit jaar (1927) voor het eerst $f 8000$ heeft uitgetrokken op de begrooting voor zware herstelling en vernieuwing van wegen en van goten en riolen, terwijl er nog een lange lijst van uit te voeren werken ligt, die in jaren niet kan afgewerkt worden..." "Schrijven van's Raads Voorzitter van 3 December 1927 No.143/7 inzake subsidie Huishoudschool”, Notulen van de op 28 December 1927 gehouden Openbare Vergadering van de Gemeenteraad van Magelang, page: 272. 
council that the school would be neutral without distinguishing the basis of religion in the learning process at its school (Notulen Gemeenteraad van Magelang, 17-1-1928: 345-347).

It is necessary to understand that the conflict of interests in the council is a natural thing to happen, especially with regard to financial affairs. Berg's disagreement over the plan to increase subsidies for poor homes and the establishment of Huishoudschool can be understood in terms of "subsidy grabs". Since 1925, two years before Merkelijn's third subsidy request for his poor house, within the budget of Magelang Municipality there was a substantial expenditure on the subsidy of the Boedi Rahajoe health social foundation (f. 3000). Boedi Rahajoe was an association in Magelang that engaged in health services for the indigenous population and Berg was among the main proponents. ${ }^{6}$ As the chief executive of Boedi Rahajoe Clinic, Berg continued to lobby for councils to support him financially. Therefore it was appropriate that Berg struggled to keep his financial interests undisturbed by others. Moreover, Boedi Rahajoe's historical roots were obviously opposite to Merkelijn in some ways.

\section{Conclusion}

The discussion above was an example of how dialogue can occur within the colonial urban environment. Although being limited, the opportunity to talk about urban affairs opened for the citizens since the implementation of decentralization. The efforts to provide social services and discussions within the municipal councils directly clarify the distinction between government/ state institutions and citizens. The discussions or dialogues can be interpreted as a process of democratic learning at the local level. This very early and limited democratization is a good foothold for the subsequent democratic processes.

This study has shown practice of citizenship which reflected in the social participation of civil society in Magelang in the early 20th century. Although the participation is limited to the urban elite, it does not reduce the importance of civil society itself. The institutional relationship between civil society and municipality in this case demonstrates more fluid citizenship practices than those previously understood in conventional Indonesian history. The practice is not the citizens attempts to demand their civil political rights, but lies in their expansion of participation. It is far from the view of social movements that disturb the colonial regime. The interpretation of civil society during

6) The commissioners of this association were C.A. Schnitzler (Assistant Resident), R.A.A. Danoesoegondo (Magelang Regent), Liem Yoe Tiang (Major China), G.J.E. Boswinkel (government doctor), L.H. Berg (retired Lieutenant Colonel Infantry in Magelang) and Willem Huender (doctor and government administration officer). Notulen van de Openbare Vergaderingen van den Gemeenteraad van Magelang 29-10-1923. Magelang: N.V. Stoomdrukkerij H.V. Maresch, p. 307. 
the colonial period was not simply refering to a society that was contrary to governmental power, eventhough without reducing the civility of society itself.

\section{References}

\section{Archives}

Notulen van de Openbare Vergaderingen Gemeenteraad van Magelang 1923

Notulen van de Openbare Vergaderingen Gemeenteraad van Magelang 1924

Notulen van de Openbare Vergaderingen Gemeenteraad van Magelang 1925

Notulen van de Openbare Vergaderingen Gemeenteraad van Magelang 1926

Notulen van de Openbare Vergaderingen Gemeenteraad van Magelang 1927

Notulen van de Openbare Vergaderingen Gemeenteraad van Magelang 1928

\section{Books}

Bambang Purwanto. "Antara Kemiskinan dan Kemakmuran: Beberapa Aspek Sejarah Ekonomi Indonesia Abad XIX dan Awal Abad XX". Laporan Penelitian. Fakultas Sastra UGM 1989-1990.

Blackburn, Susan (2012). Jakarta :Sejarah 400 Tahun.Jakarta: Penerbit Masup Jakarta. Colombijn, Freek (2006). Paco-paco (kota) Padang Sejarah Sebuah Kota di Indonesia Abad ke-20 dan Penggunaan Ruang Kota. Yogyakarta: Penerbit Ombak.

Colombijn, Freek \& Joost Cote (2014). Cars, Conduits, and Kampongs The Modernization of the Indonesian City, 1920-1960. KITLV, Vol 295.

Dhont, Frank (2005). Nasionalisme Baru Intelektual Indonesia Tahun 1920an. Yogyakarta: UGM Press

Ds.Merkelijn(1941).26jarenopnetZendingsveld.D.A.Daamen'sUitgeversmaatscappij N.V.'s- Gravenhage.

Elson, R.E. (2009). The Idea of Indonesia, Sejarah Pemikiran dan Gagasan. Jakarta: Serambi.

Frederick, W. (1978). "Indonesian Urban Society in Transition: Surabaya 19261946", Tesis Ph.D., University of Hawaii.

Furnivall, J.S. (1976). Netherlands India: A Study of Plural Economy (terj.). Cambridge: Cambridge University Press.

Guan, Lee Hock (Ed) (2004). Civil Society in Southeast Asia. Singapore: ISEAS

Hilman Latief (2010). Melayani Umat Filantropi Islam dan Ideologi Kesejahteraan Kaum Modernis. Jakarta: Gramedia Pustaka Utama.

Jamil Gunawan, Sutoro Eko Y unanto, Anton Birowo \& Bambang Purwanto (2005). Desentralisasi, Globalisasi dan Demokrasi Lokal.Jakarta: LP3ES.

Nas, P.J.M. (1990). "The Origin and Development of the Urban Municipality in Indonesia", Sojourn: Journal of Social Issues in Southeast Asia, Vol. 5(1), pp. 86112.

Nordholt, Henk Schulte (2011). "Modernity and Cultural Citizenship in the Netherlands Indies: An Ilustrated Hypothesis", Journal of Southeast Asian Studies, 42 (3), pp. 435-457.

O’Donnell, Guillermo (1993). Transisi Menuju Demokrasi: Tinjauan Berbagai Perspektif.Jakarta: LP3ES

Petrik Matanasi (2012). Pribumi Jadi Letnan KNIL. (tanpa tempat terbit): Trompet Book. 
Putnam, Robert (1993). Making Democracy Work: Civic Tradition in Modern Italy. Princeton: Princeton University Press.

Sartono Kartodirdjo (2014). Pengantar Sejarah Indonesia Baru: Sejarah Pergerakan Nasional (Jilid 2). Yogyakarta: Ombak.

Scholten, Elsbeth Locher (1999). "The Colonial Heritage of Human Rights in Indonesia: The Case of the Vote for Women, 1916-4", Journal of Southeast Asian Studies, Vol. 30(1), pp. 54-73.

Vickers, Adrian (2011). A History of Modern Indonesia (terjm). Yogyakarta: Insan Madani. 